\title{
СИНТЕЗ И ФОТОХИМИЧЕСКИЕ СВОЙСТВА ЗАМЕЩЕННЫХ СУБФТАЛОЦИАНИНОВ БОРА - ПЕРСПЕКТИВНЫХ ФОТОСЕНСИБИЛИЗАТОРОВ ДЛЯ ФОТОДИНАМИЧЕСКОЙ ТЕРАПИИ
}

\author{
Т.В. Дубинина' \\ В.А. Кузьмин ${ }^{2}$, Е.Р. Милаева' \\ ${ }^{1}$ Химический факультет, МГУ имени М.В. Ломоносова, \\ 119991, Россия, Москва, Ленинские горы, 1. \\ ²ИБХФ им. Н.М. Эмануэля РАН, 119334, Россия, Москва, ул. Косыгина, 4.
}

DOI: 10.19163/MedChemRussia2021-2021-121

E-mail: dubinina.t.vid@gmail.com

Объединение в одной молекуле свойств фотосенсибилизатора, способного к генерации синглетного кислорода и флуоресцентной метки, является важным направлением поиска новых препаратов для ФДТ. Перспективными кандидатами являются субфталоцианины, которые не подвержены агрегации, способны генерировать $\mathrm{O}_{2}{ }^{1}$ и обладают флуоресценцией в диапазоне 500-600 нм.

В данной работе синтезированы субфталоцианины, структурно модифицированные по двум направлениям: за счёт периферических групп (R) и аксиального лиганда у атома бора (L). B качестве периферических групп для изучения проявления эффекта тяжёлого атома использовали галоген-замещенные субфталоцианины $(\mathrm{F}, \mathrm{Cl}$ и I), в качестве периферических заместителей вводили арилокси-группы.

Определены квантовые выходы $\left(\Phi_{f}=0,13 \div 0,50\right)$ и кинетика гибели флуоресценции субфталоцианинов ( $\tau=0,3 \div 3$ нс). С использованием флеш-фотолиза зарегистрировано формирование триплетных полос поглощения в областях 420-500 нм и 600-800 нм с временами жизни 0,6-2,4 мс. По результатам измерений спектров фосфоресценции синглетного кислорода ( $\lambda \max _{1270}$ нм), показано, что полученные субфталоцианины обладают высокими квантовыми выходами генерации $\mathrm{O}_{2}{ }^{1}\left(\Phi_{\Delta}=0,46 \div 0,74\right)$, возрастающими в ряду: ${ }^{\text {Pho }} \mathrm{SubPcCl}<{ }^{\text {Pho }} \mathrm{SubPcOPh}=$ EtoocPhoSubPcCl $<$ F SubPcCl $<$ 'SubPcCl.

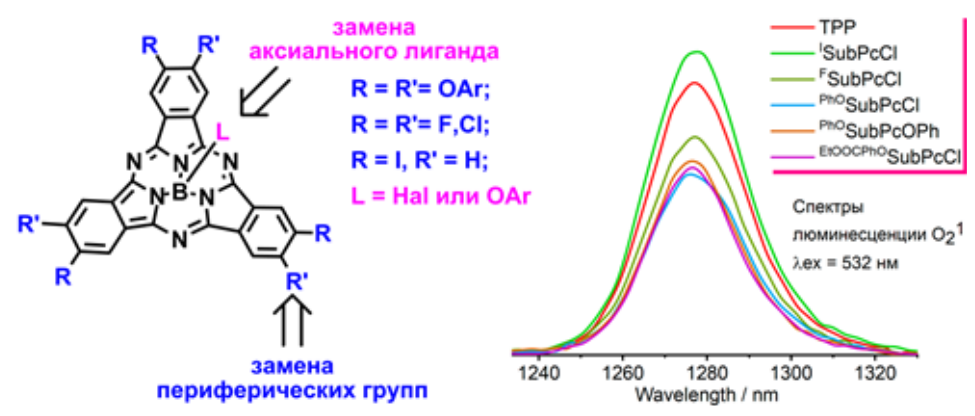

Работа выполнена при финансовой поддержке гранта РФФИ № 21-33-70004 мол_а_мос.

$$
-121 \text { - }
$$

